\title{
肉盛溶接部の曲 げ延性改善方策*
}

一高純度フェライト系ステンレスクラッド鎝の䧍接に関する研究（第 3 報）一 中尾嘉邦 $* *$, 西本和俊**, 山崎和信***, 野井伸悟****,塚原 宏*****, 原 泰弘 $* * * * *$

Countermeasure for Improvement of the Bend Ductility of the Overlay Weld*

-Study on Welding of the Low Interstitial Ferritic Stainless Clad Steel (Report 3)-

by Yoshikuni Nakao**, Kazutoshi Nishimoto**, Kazunobu Yamazaki***,

Shingo Noi****, Hiroshi Tsukahara***** and Yasuhiro Hara*****

The countermeasure for improvement of the bend ductility of the low interstitial ferritic stainless steel overlay welds has been investigated.

The addition of stabilizing elements, especially zirconium, up to about $0.4 \%$ to the first layer of the ferritic stainless steel overlay welds with $30 \%$ chromium on a low alloy steel improved its bend ductility. The bend ductility of the overlay welds was also improved with decreasing the chromium content in the first layer of the weld metal.

On the basis of these results, a composition of $19 \mathrm{Gr}-2 \mathrm{Mo}-0.25 \mathrm{Zr}-\mathrm{Fe}$ was recommended for the filler metal for the first layer of the $30 \mathrm{Cr}-2 \mathrm{Mo}$ steel overlay welding on a low alloy steel in order to ensure a good weld ductility.

Key Words: Low intenstitial ferritic stainless steel, Overlay weld, Bend ductility, Stabilizing element, Cr content, Filler metal, Improvement

\section{1. 緒詈}

前報1.2)に抢いて，高純度フェライト系ステンレス鋁 肉盛溶接部に生じる脆化機構を検討した結果，肉盛溶接 部の航化の主要因は $\mathrm{Cr}$ 炭化物の結晶粒界上への析出に 起因した Hall-Petch 係数 (Ky) の上昇による塑性楥和 能の低下であり，二次的要因として，溶接後熱処理（以 後 PWHT と呼ぶ過程における $475^{\circ} \mathrm{C}$ 腃化及び結晶粒 の粗大化手肉盛溶接部の脆化に関与していることを明ら 加した。

ところで，Crよりも $\mathrm{C}$ との親和力の強い安定化元素 のフェライト系ステンレス鋼中への添加は，素材及び溶 接部の機械的特性の改善に有効であるととはよく知られ た事実でありてれに関する報告3-6) が数多くなされてい

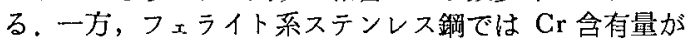

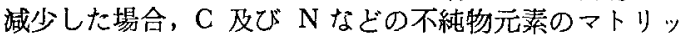
クス中への固滘量が增大する絬果，乙れらの不純物元素 による污染に起因した脆化に対する抵抗性が问上する。

また Cr 含有量の低下に伴い， $475^{\circ} \mathrm{C}$ 脆化の軽减古期待 される。

以上のような観点より，本報においては肉盛溶接部の 曲げ延性の改善を目的として，第一層目の溶接に用いる 下盛溶加棒への安定化元素（ここでは Nb，Ti Zr）の添加, 下盛溶加棒の低 Cr 化ならびにその兩者の

\footnotetext{
“原稿受付 昭和62年11月11日 昭和60年度秋季全国大会で発表

**正員大阪大学工学部 Member, Faculty of Engineering, Osaka University

“.”正 員 大服大学大学院 (現在 日新製銅 (珠)) Member, Graduate school,Osaka University(Present address:Nisshin Steel Co.,Ltd.

***正員 (株)新潟鉄工所 Member, Niigata Engineering Co.,Ltd.

(株) 新鼬鉄工所 Niigata Engineering Co.,Ltd.
}

複合効果を期待した安定化元素添加低 Cr 系下盛溶加棒 を採用時の曲げ延性について系統的に調查し，曲げ延性 改善に最も有効である下盛溶加棒組成について検討を行 なった。

\section{2. 供試材料ならびに実験方法}

Table 1 亿第一廨目肉盛溶接部の作製に用いた安定化 元素添加 $30 \mathrm{Cr}-2 \mathrm{Mo}$ 鋼溶加棒の化学組成を示す. これ らは，安定化元菜として $\mathrm{Nb}, \mathrm{T}_{\mathrm{i}}$ 及び $\mathrm{Zr}$ を選び，各々 の安定化元素の添加量を約0. 1 0.45\% の籁囲内で $3 \sim 4$ 段階に変化させた溶加棒である。溶加棒径は $1.8 〜 2.3$ $\mathrm{mm}$ である。

Table 2 には肉盛溶接部の曲げ延性に及ばす低 $\mathrm{Cr}$ 化 の効果及じ安定化元素之低 $\mathrm{Cr}$ 化の複合効果を検討する ため使用した下盛溶加棒ならびに母材の化学組成を合せ て示す。これらの溶加棒俻は 1.8〜2.0 mm である。な お, Table 1 及び Table 2 中の $19 \mathrm{Cr}-2 \mathrm{Mo}$ 鋼及び 30 $\mathrm{Cr}-2 \mathrm{Mo}$ 鋼溶加棒以外のものは奏験室的に真空溶解に より溶製し，線引き加工を行なって作製したものであ る. Table 1 及び Table 2 に示す溶加棒を用いて板厚 $38 \mathrm{~mm}$ の炭素銅板上にティグ法に上り浴込率15\%〜35\% の範囲で下盛溶接を行なった後，その上層には市販の $30 \mathrm{Cr}-2 \mathrm{Mo}$ 鈵溶加棒（Table 2 中の HM）を用いて溶 込率 $25 \%$ で肉盛溶接を行なった。このようにして作製し た肉盛溶接部に対して，PWHT 後，側曲げ試験を実施 し，曲げ延性を評価した。

肉盛溶接部の組織観察として光学影微鏡及び走查型電 子蹎微鏡 (以後 SEM と呼ぶ) 観察を行なった，析出物 の同定には抽出残渣によるX線回折及び抽出レプリカに 上る透過型電子顕微鏡（以後 TEM 々呼ふ）観察を行 なった、破面観察に際しては，SEM により割れ破面の 詳細な検討を実施した。

なお，側曲げ武験方法の詳細は第 1 報り之同様の方法 
Table 1 Chemical compositions of filler metals (mass $\%$ )

\begin{tabular}{|c|c|c|c|c|c|c|c|c|c|c|c|c|c|c|c|}
\hline Mark & Filler metal & $\begin{array}{c}\text { Diameter of } \\
\text { filler netal } \\
(\mathrm{m})\end{array}$ & c & si & $M n$ & P & s & $\mathrm{Cr}$ & Mo & $N i$ & A1 & N & $\mathrm{Nb}+\mathrm{Ta}$ & $2 r$ & Others \\
\hline $\mathrm{HZZ}$ & \multirow{4}{*}{$\begin{array}{l}2 r \text { containing } \\
30 \mathrm{Cr}-2 \mathrm{MO} \text { stee }]\end{array}$} & 2.30 & 0,0034 & - & - & - & - & 30.6 & 1.98 & - & 0.26 & 0.0076 & 0.144 & 0.093 & - \\
\hline H22 & & 2.34 & 0.0024 & 0.21 & 0.037 & 0.015 & 0.010 & 30.5 & 1.90 & 0.144 & 0.22 & 0.0078 & 0.117 & 0.20 & - \\
\hline Hiz & & $2.0 \$$ & 0.0031 & 0.18 & 0.018 & 0.012 & 0.008 & 30.2 & 1.98 & - & 0.28 & 0.0076 & - & 0.28 & - \\
\hline HZ4 & & 2.00 & 0.0027 & 0.18 & 0.018 & 0.010 & 0.009 & 31.2 & 2.00 & - & 0.28 & 0.0066 & - & 0,37 & - \\
\hline HII & \multirow{3}{*}{$\begin{array}{l}\tau i \text { contal ining } \\
\text { 30C } r \text {-2Mo steel }\end{array}$} & 1.84 & 0.007 & - & - & - & - & - & - & - & - & 0.006 & - & - & 0.101 \\
\hline Hๆ2 & & 1.84 & $0.0 \mathrm{n}$ & - & - & - & - & - & - & - & - & 0.013 & - & - & $0.32 \mathrm{Ti}$ \\
\hline $\mathrm{H} \div 3$ & & $1.8 t$ & 0.006 & 0.21 & 0.077 & 0.020 & 0.005 & 30.10 & 1.80 & - & - & 0.004 & - & - & $0.42 \mathrm{Ti}$ \\
\hline HNI & \multirow{4}{*}{$\begin{array}{l}\text { No conta ining } \\
30 \mathrm{Cr}-2 \mathrm{Mo} \text { stee } 1\end{array}$} & 2.04 & 0.0028 & 0.22 & 0.021 & 0.013 & 0.009 & 30.2 & 2.04 & 0.16 & 0.22 & 0.0084 & 0.194 & - & $\sim$ \\
\hline HN2 & & 2.07 & 0.0030 & - & - & -- & - & 30.8 & - & - & 0.23 & 0.0094 & 0.333 & - & - \\
\hline HN3 & & $2.0 \ddagger$ & 0.0030 & - & - & - & - & 30.4 & -. & - & 0.21 & 0.0078 & 0.374 & - & - \\
\hline HN4 & & 2.04 & 0.0028 & - & - & - & $=$ & 30.4 & - & - & 0.26 & 0.0083 & 0.464 & - & - \\
\hline
\end{tabular}

Table 2 Chemical compositions of filler metals and base metal (mass \%)

\begin{tabular}{|c|c|c|c|c|c|c|c|c|c|c|c|c|c|c|}
\hline Merk & $\begin{array}{l}\text { Filler metal } \\
\text { or base metal }\end{array}$ & $\begin{array}{l}\text { Diameter of } \\
\text { f filler metal } \\
(\mathrm{mm})\end{array}$ & c & si & $M n$ & $\mathrm{P}$ & $s$ & $\mathrm{Cr}$ & Mo & $\mathrm{Ni}$ & Al & N & $\mathrm{Nb}+\mathrm{Ta}$ & $2 r$ \\
\hline$U M$ & $15 \mathrm{Cr}-2 \mathrm{Mr}$ stee 1 & 1.84 & 0.0040 & 0.12 & 0.03 & 0.010 & 0.004 & 14.99 & 1.94 & - & - & 0.004 & 0.15 & - \\
\hline$L M$ & $19 \mathrm{Cr}-2 \mathrm{MO}$ steel & 1.84 & 0.009 & 0.18 & 0.27 & 0.024 & 0.004 & 19.04 & 2.48 & - & - & 0.011 & 0.22 & - \\
\hline$M$ & $26 \mathrm{Cr}-2 \mathrm{M}_{0}$ steel & 1.80 & 0.0021 & 0.15 & 0.09 & 0.012 & 0.008 & 26.20 & 1.40 & - & - & 0.0065 & 0.14 & - \\
\hline HIH & $30 \mathrm{Cr}$-2Mo stee 1 & 2.04 & 0.0019 & 0.16 & - & 0.016 & 0.011 & 29.40 & 1.98 & - & - & 0.0069 & 0.10 & - \\
\hline U2I & \multirow{4}{*}{$\begin{array}{l}2 r \text { containing } \\
15 C r-2 M_{0} \text { steel }\end{array}$} & 1.84 & 0.0038 & 0.13 & 0.02 & 0.010 & 0.005 & 15.00 & 1.98 & - & - & 0.0036 & 0.15 & 0.14 \\
\hline U22 & & 1.84 & 0.0027 & 0.13 & 0.02 & 0.010 & 0.005 & 15.33 & 2.02 & - & - & 0.0032 & 0.15 & 0.26 \\
\hline 623 & & $1.8 \phi$ & 0.0035 & 0.13 & 0.02 & 0.010 & 0.005 & 14.93 & 2.00 & - & - & 0.0034 & 0.15 & 0.40 \\
\hline U24 & & 1.84 & 0.0051 & 0.13 & 0.02 & 0.010 & 0.005 & 15.00 & 1.99 & - & - & 0.0054 & 0.15 & 0.43 \\
\hline$|2|$ & \multirow{5}{*}{$\begin{array}{l}\text { 2r containing } \\
19 \mathrm{Cr}-2 M_{0} \text { steel }\end{array}$} & $2.0 \phi$ & 0.003 & 0.10 & 0.05 & 0.017 & 0.0022 & 19.35 & 1.86 & - & - & 0.0047 & 0.070 & 0.092 \\
\hline LZ2 & & 2.04 & 0.0019 & 0.07 & 0.05 & 0.017 & 0.0022 & 18.78 & 1.84 & - & - & 0.0036 & 0.074 & 0.164 \\
\hline$L 23$ & & $2.0 \phi$ & 0.0021 & 0.07 & 0.04 & 0.017 & 0.0035 & 19.80 & 1.88 & - & - & 0.0039 & 0.066 & 0.248 \\
\hline L24 & & 2.00 & 0.0030 & 0.11 & 0.06 & 0.012 & 0.0030 & 17.95 & 2.00 & - & - & 0.0040 & - & 0.410 \\
\hline L25 & & 2.04 & 0.0013 & 0.12 & 0.06 & 0.008 & 0.0040 & 18.89 & 1.96 & - & - & 0.0035 & - & 0.530 \\
\hline $\mathrm{MZ1}$ & \multirow{4}{*}{$\begin{array}{l}2 r \text { contalning } \\
26 \mathrm{Cr}-2 \mathrm{M}_{0} \text { steel }\end{array}$} & 1.84 & 0.0073 & 0.19 & 0.06 & 0.015 & 0.005 & 26.04 & 1.83 & - & - & 0.0062 & 0.14 & 0.10 \\
\hline Ma2 & & $1.8 \phi$ & 0.0029 & 0.19 & 0.06 & 0.015 & 0.005 & 26.04 & 1.83 & - & - & 0.0052 & 0.14 & 0.23 \\
\hline$M 23$ & & $1.8 \phi$ & 0.0045 & 0.19 & 0.06 & 0.015 & 0.005 & 26.04 & 1.83 & - & - & 0.0054 & 0.14 & 0.43 \\
\hline NZ4 & & $1.8 \phi$ & 0.0046 & 0.19 & 0.06 & 0.015 & 0.005 & 26.04 & 1.83 & - & - & 0.0056 & 0.14 & 0.46 \\
\hline BM & Carbon stee I & $38 *$ & 0.08 & 0.30 & 1.10 & 0.013 & 0.0030 & 0.15 & 0.15 & - & - & $=$ & - & - \\
\hline
\end{tabular}

により行なった。

\section{3. 肉盛溶接部の曲げ延性改善に向けての 検討}

\section{1 下盛溶加棒中の安定化元絜添加の影響}

下盛材として $\mathrm{Nb}$ ，Ti 及び $\mathrm{Zr}$ を添加した $30 \mathrm{Cr}-2$ Mo 鋼溶加棒を用いて肉盛溶接を行ない，それぞれの元 素の曲げ姃性に及ぼす影響について検討を行なった。

Table 1 に示すように種々の $30 \mathrm{Cr}-2 \mathrm{Mo}-\mathrm{Zr}$ 鋼溶加 棒中には安定化元素として添加された $\mathrm{Zr}$ 以外に約 0.1 $960 \mathrm{Nb}$ が合有されている.乙の理由は, 本錀が实験空 的に真空溶解により作製された鋼であり，溶解用の母合 金亡して市肘の $30 \mathrm{Cr}-2 \mathrm{M}_{0}$ 鋼（約 $0.1 \% \mathrm{Nb}$ を含有）を 用いたためである。同様のととが，真空溶解鋼である $30 \mathrm{Cr}-2 \mathrm{Mo}-\mathrm{Ti}$ 銿に対してもいえる。乙のため, Zr あ しくは $\mathrm{T}_{\mathrm{i}}$ を添加した溶加棒を用いた肉盛溶接部におい て観察される現象は放密には $\mathrm{Zr}+\mathrm{Nb}$ もしくは $\mathrm{Ti}+\mathrm{Nb}$ の複合効果に起因するもの上考えるのが罗当であろう。 しかしながら，ここでは，甫服の高純度 $30 \mathrm{Cr}-2 \mathrm{Mo}$ 鋼 組成に意図的に追加添加を行なったという観点より，こ れらの溶加棒を用いた場合の変化をそれぞれ $\mathrm{Zr}$ 及じ Ti の添加効果として検討を行なう。なお，後述するよう を, $\mathrm{Nb}, \mathrm{Ti}$ 及び $\mathrm{Zr}$ のうち, $\mathrm{Nb}$ の添加量の0.46\%ま での增加においては肉盛溶接部の機械的性質はほとんど 変化しないことが確認されており，ての意味です $\mathrm{Zr}+$ -

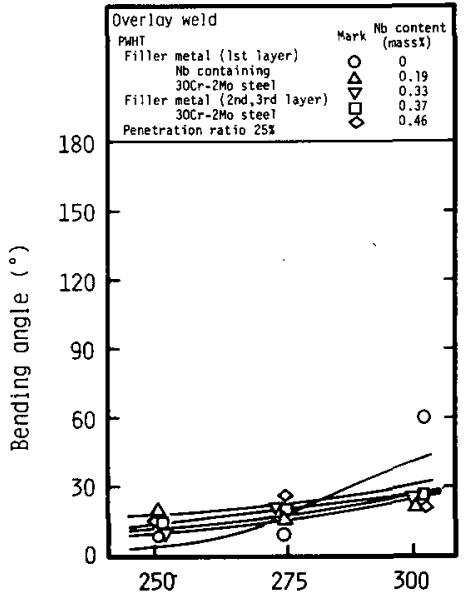

Fig. 1 Result of side-bend test of Nb containing overlay welds post heat-treated

$\mathrm{Nb}$ もしくは $\mathrm{Ti}+\mathrm{Nb}$ を含有する溶加棒を用いて作製さ れた肉盛溶接部に生じる現象を $\mathrm{Zr}$ あしくは Ti の肉盛 溶接部に対する影響と仮定してさしつかえないものと考 えられる。

Fig. 1〜3 に下盛材としてそれぞれ種々の30 Cr-2 Mo- 


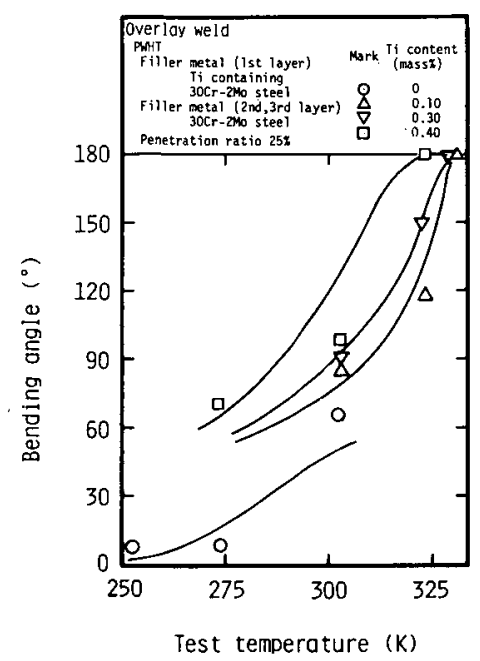

Fig. 2 Result of side-bend test of Ti containing overlay welds post heat-treated

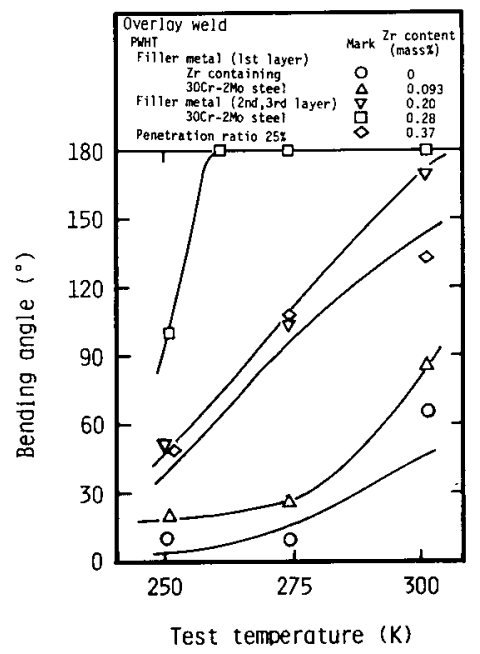

Fig. 3 Result of side-bend test of $\mathrm{Zr}$ containing overlay welds post heat-treated

$\mathrm{Nb}$ 銅, $30 \mathrm{Cr}-2 \mathrm{Mo}-\mathrm{Ti}$ 鋼及び $30 \mathrm{Cr}-2 \mathrm{Mo}-\mathrm{Zr}$ 鋼溶加 棒を用い，溶込率25\%で作製された肉盛溶接部 PWHT 村の側曲舛試験結果を示す。

下盛溶加棒へ $\mathrm{Nb}$ を添加した場合, 今回実施した側曲 げ試験温度範囲内（253 K 303 K）においては, 試験片 は大部分 $30^{\circ}$ 以下の曲げ角度で割れが発生しており, 因 盛溶接部の曲げ延性改善効果はほとんど珰められない。

下盛溶加棒へ $\mathrm{Ti}$ を添加した場合, Nb 添加の場合と 比べて同一側曲げ式験温度での割れ発生時の曲げ角度は 上昇し，曲げ延性の改善傾向のあることがわかる。しか しながら，その改善幅はわずかである。すなわち，肉盛 浴接部の側曲げ式験において，割れが発生するととなく $180^{\circ}$ 曲げが可能な最む低い温度（以後 CCTT と呼ぶ） は $0.4 \% \mathrm{Ti}$ 添加の場合 $323 \mathrm{~K}$ であるが, $\mathrm{Ti}$ 無添加の場 合に比べて $10 \mathrm{~K}$ の CCTT の低下にとどまる（Fig. 2 と Fig. 4 参照).

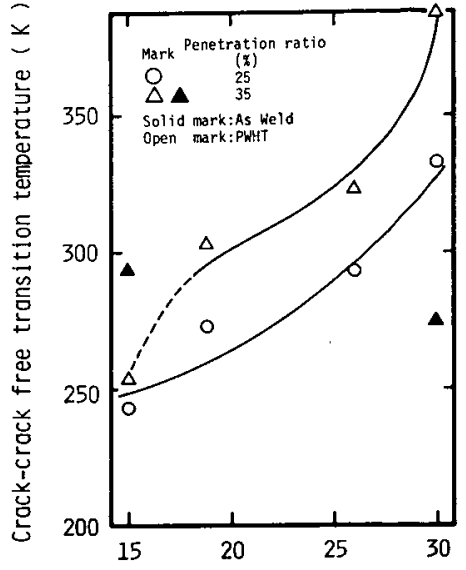

$\mathrm{Cr}$ content in the flller metal used for the first layer (moss\%)

Fig. 4 Relation between $\mathrm{Cr}$ content in the filler metal used for the first layer of the overlay weld metal and crack-crack free transition temperature by side-bend test

これに対し，下盛溶加棒への $\mathrm{Zr}$ 添加による肉盟溶接 部の曲げ延性改善効果は大きく，約 $0.1 \% \sim 0.37 \%$ まで の全ての $\mathrm{Zr}$ 添加量において Zr 無添加の溶加棒を用い た内盛溶接部に比へて曲げ延性の改善傾向を有している ととがわかる。特に，0.28\%の $\mathrm{Zr}$ 添加溶加棒の採用に より，肉盛溶接部の CCTT は $263 \mathrm{~K}$ まで低下し， $\mathrm{Zr}$ 無添加の市販の $30 \mathrm{Cr}-2 \mathrm{Mo}$ 鋼溶加棒を用いた肉盛溶接 部の CCTT $(333 \mathrm{~K})$ 加ら比べると $70 \mathrm{~K}$ の CCTT の 改善が可能となった。

以上の結果より，本試験に括いて採用した安定化元素 である $\mathrm{Nb}$ ，Ti 及び $\mathrm{Zr}$ の中では溶加棒への $\mathrm{Zr}$ の添 加が高純度フェライト采ステンレス銅肉盛溶接部の曲げ 延性改善に最あ有効であることが明らかとなった。

\section{2 下盛溶加棒中の $\mathrm{Cr}$ 量の影響}

下盛材として市販の高純度 $30 \mathrm{Cr}-2 \mathrm{Mo}$ 鋼溶加棒より $\mathrm{Cr}$ 量を低減させた溶加棒を用いた場合の肉盛溶接部の 曲げ延性について調查を行ない，Cr 量低减による延性 改善効果について検討を行なった．側曲げ試験片の作製 に際しては, 初首の溶接に Table 2 に示す $26 \mathrm{Cr}-2 \mathrm{Mo}$ 鋼, $19 \mathrm{Cr}-2 \mathrm{Mo}$ 鋼及び $15 \mathrm{Cr}-2 \mathrm{Mo}$ 鋼溶加棒を用いて 溶込率 $25 \%$ または $35 \%$ の条件で下盛溶接に行なった後， 第二, 三層目の溶接は市販の高純度 $30 \mathrm{Cr}-2 \mathrm{Mo}$ 銅溶加 棒を用いて溶込染25\%の条件で行なった，Fig. 4 には下 盛溶加棒中の $\mathrm{Cr}$ 量とその溶加棒を用いて作製した肉盛 溶接部 PWHT 材の曲げ試験により求められる CCTT との関係を示す。なお，図中には初風から市販の $30 \mathrm{Cr}-$ $2 \mathrm{Mo}$ 鋼溶加棒を用いて溶込率 $25 \%$ 及び $35 \%$ で作製した 肉盛溶接部 PWHT 材（溶込率35\%については AW 材 あ含む)の CCTT についても合せて示している.

市眅の $30 \mathrm{Cr}-2 \mathrm{Mo}$ 鋼溶加棒に比へて Cr 量を低減さ せた $26 \mathrm{Cr}-2 \mathrm{Mo}$ 鋼下盛溶加棒を用い, 溶込率 $25 \%$ で作 製した肉盛溶接部 PWHT 材の CCTT は $293 \mathrm{~K}$ 及び溶 込染 $35 \%$ の場合の CCTT は $323 \mathrm{~K}$ である。

$19 \mathrm{Cr}-2 \mathrm{Mo}$ 鍽下盛溶加棒を用いた場合の肉盛溶接 部 PWHT 材の CCTT は溶込率25\%で $273 \mathrm{~K}$, 溶込率 $35 \%$ 
で $303 \mathrm{~K}$ となる。

さらに, Cr 量の低減を図った $15 \mathrm{Cr}-2 \mathrm{Mo}$ 鋼下盛溶 加棒を用い, 溶込率 $25 \%$ で作製した肉盛溶接部 PWHT 材の CCTT は $243 \mathrm{~K}$ であり, 溶込率 $35 \%$ で $253 \mathrm{~K}$ と なる

このように, 肉盛溶接部 PWHT 材の曲げ延性は, 下 盛溶加棒中の $\mathrm{Cr}$ 量の低下に伴い, 改善される傾向にあ るととがわかる。

ところで, Fig.4 中には, 下盛溶加棒として $15 \mathrm{Cr}$ $2 \mathrm{Mo}$ 鋼及び $30 \mathrm{Cr}-2 \mathrm{Mo}$ 鋼溶加棒を用いて溶込率 $35 \%$ で作製した肉盛溶接部 AW 材の CCTT 屯合せて示し ている. AW 材の曲げ延性に注目すると, 下盛材として $30 \mathrm{Cr}-2 \mathrm{Mo}$ 鋼溶加棒を用いた溶込率 $35 \%$ 時の肉盛溶 接 部 AW 材の CCTT が $273 \mathrm{~K}$ であるのに対し, $15 \mathrm{Cr}$ $2 \mathrm{Mo}$ 鋼溶加棒使用時のそれは $293 \mathrm{~K}$ と $\mathrm{Cr}$ 量が低下し ているにあかかわらず，曲げ延性は逆に劣化しているの がわかる。ささらに，15 Cr-2 Mo 鋼溶加棒を用いた溶込 率35\%の肉盛溶接部においては, AW 材の CCTT は $293 \mathrm{~K}$, PWHT 材のそれは $253 \mathrm{~K}$ と AW 材の曲げ延性 は PWHT 材のそれよりあ劣化しているととがわかる。 この結果は, 第 1 報1) において示した $30 \mathrm{Cr}-2 \mathrm{Mo}$ 鋼溶 加棒を下盛材として用いた肉盛溶接部の曲げ延性が PW HT の実施により著しく劣化するという事実と逆の傾向 を示している.

組織観察の結果, $15 \mathrm{Cr}-2 \mathrm{Mo}$ 鋼溶加棒を下盛材とし て用い, 溶込率 $35 \%$ で作製した肉盛溶接部中の溶融境界 線近傍の結晶粒界付近には, Fig. 5 に見られるようなマ ルテンサイトの組織が観察された。すすなわち, 本溶加棒 の $\mathrm{Cr}$ 含有量は $15 \%$ 之他の溶加棒の $\mathrm{Cr}$ 量に比へて低い こと, かつ溶込率が $35 \%$ と比較的高いいため, 肉盛溶接 部の組織はシェフラーの状態図 ${ }^{7)}$ から予想されるように フェライト+マルテンサイト組織になるあのと推察さ れ, この際生じたマルテンサイトが肉盛溶接部 $\mathrm{AW}$ 材 の曲げ延性を著しく劣化させたあの之考えられる。しか しながら，AW 材のマルテンサイトは，PWHT を行な うことにより焼むどされ, その結果, Fig. 4 中に示され たように PWHT 材の曲げ延性は AW 材に比べて良好 な值となったものと推察される。

ところで, 実際の溶接施工においては, 使用するク ラッド鋼の板厚が規格等で定められた PWHT 実施の臨 界板厚に満たない場合，PWHT は不要となる。これら のことを考虑した場合，実溶接施工に適用される下盛材 中の $\mathrm{Cr}$ 量の下限は肉盛溶接部の機械的特性を少化させ る危険性のあるマルテンサイトが生成するか否かによっ て制限されるといえる。

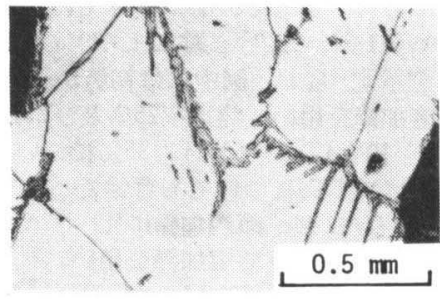

Fig. 5 Microstructure of the $15 \mathrm{Cr}-2 \mathrm{Mo}$ steel overlay weld metal adjacent to the bond
以上の結果より, 下盛材中の $\mathrm{Cr}$ 量の低減により, 肉 盛溶接部の曲げ延性が改善できることが確認されたが, その場合の $\mathrm{Cr}$ 量は $\mathrm{AW}$ 状態でマルテンサイトを生成 させず, かつ大きな曲げ延性改善効果が得られるように 設定することが必要であり, 本実験で用いた溶加棒では $19 \mathrm{Cr}-2 \mathrm{Mo}$ 鋼下盛溶加棒を用いた場合が最も良い結果 が得られた。

\section{4. 下盛溶加棒の Zrr 添加低Cr化による 肉盛溶接部の曲げ延性改善効果}

前述のごとく, 高純度フェライト系ステンレス鋼肉盛 溶接部の曲げ延性は安定化元素を添加した下盛溶加棒の 使用により改善できる可能性がある。特に，0.28\% Z Z を添加した $30 \mathrm{Cr}-2 \mathrm{Mo}$ 鋼下盛溶加棒を用い, 溶込率 25 \%で作製した肉盛浴接部 PWHT 材の CCTT は $263 \mathrm{~K}$ 之極めて良好な曲げ延性を得ることが確認された，しか しながら， $30 \%$ Cr を含有するフェライト系ステンレス 鋼においては，良好な曲げ延性を破保できる最適 $\mathrm{Zr}$ 添 加量範囲は極めて狭く, 実施工時の種々の不確定要因を 考慮した場合, 本溶加棒の使用は曲げ延性改善策とし て,それだけでは必ずしも十分であるとは言い難い，

一方, $\mathrm{Cr}$ 量を低減したフェライト系ステンレス鋼下 盛溶加棒の採用もまた, 肉盛溶接部の曲げ延性改善に有 効であることが判明している，しかしながら，ての方策 においても $19 \mathrm{Cr}-2 \mathrm{Mo}$ 鋼下盛溶加棒を用いた肉盛溶接 部の CCTT は $273 \mathrm{~K}$ (溶込率 $25 \%$ ) 303 K (溶込率35 \%) と市販の $30 \mathrm{Cr}-2 \mathrm{Mo}$ 鋼溶加棒を用いた肉盛溶接部 の曲げ延性に比べて著しい改善が認められるあのの, そ の改善幅は実構造物の製作を想定した場合，さらに改善 の余地があるといえる.

以上の観点より，より大幅な曲げ延性改善効果を得る ため, 安定化元素中で曲げ延性改善に最も有効であった $\mathrm{Zr}$ 添加と低 $\mathrm{Cr}$ 化の複合効果について検討を行なうこ とにした。

\section{1 曲げ延性改善のための最適 $\mathrm{Cr}$ 量ならびに $\mathrm{Zr}$ 添加量の検討}

Fig. 6 8 に下盛材としてそれぞれ $\mathrm{Zr}$ 量を種々変化

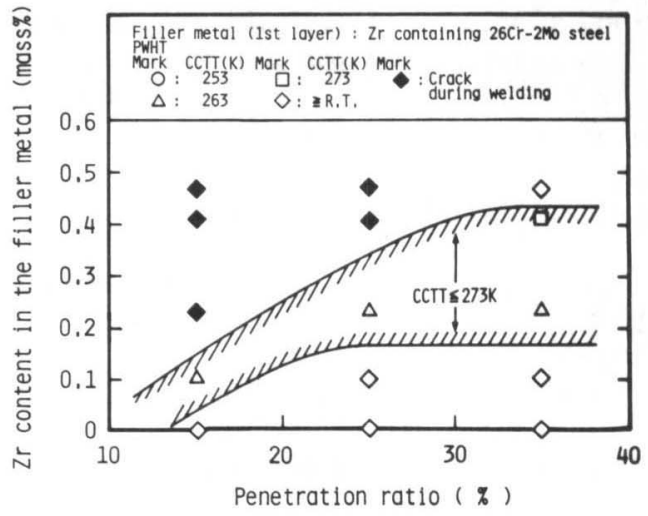

Fig. 6 Optimum $\mathrm{Zr}$ content range to obtain sufficient bend cutility (CCTT $<273 \mathrm{~K}$ ) indicating as a shaded region as a function of penetration ratio Filler metal (1st layer) : $\mathrm{Zr}$ containing $26 \mathrm{Cr}-2 \mathrm{Mo}$ steel 


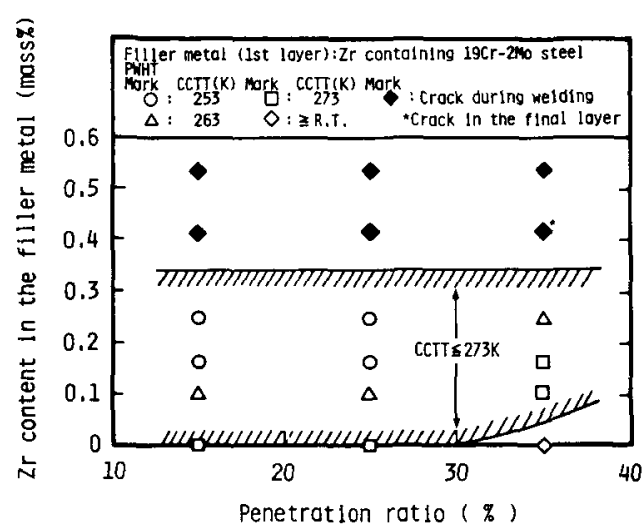

Fig. 7 Optimum Zr content range to obtain sufficient bend ductility (CCTT $<273 \mathrm{~K}$ ) indicating as a shaded region as a function of penetration ratio Filler metal (1st layer) : $\mathrm{Zr}$ containing $19 \mathrm{Cr}-2 \mathrm{Mo}$ steel

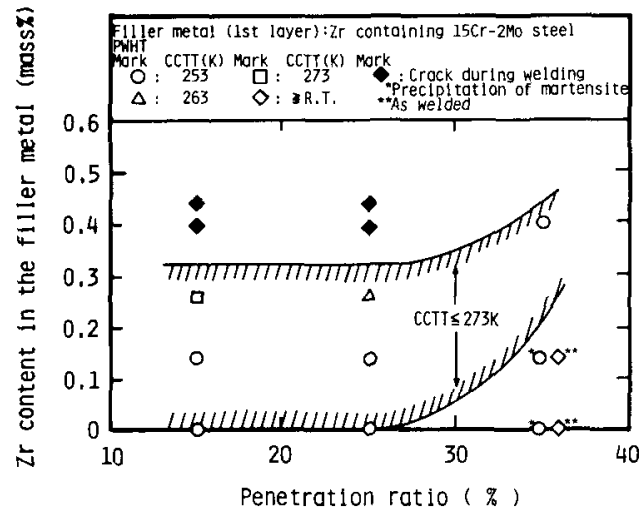

Fig. 8 Optimum $\mathrm{Zr}$ content range to obtain sufficient bend ductility (CCTT $<273 \mathrm{~K}$ ) indicatining as a shaded region as a function of penetration ratio Filler metal (1st layer) : Zr containing $15 \mathrm{Cr}-2 \mathrm{Mo}$ steel

させた $26 \mathrm{Cr}-2 \mathrm{Mo}$ 鋼, $19 \mathrm{Cr}-2 \mathrm{Mo}$ 鋼及び $15 \mathrm{Cr}-2 \mathrm{Mo}$ 鋼溶加棒を用い，実施工時の種々の不確定要因を考虑し て，溶込平を $15 \%$ ３5\%の範囲で変動させた場合，肉盛 溶接部の曲げ延性の指標である CCTT がどの上うに変 化するかについて調查を行なった結果を示す. 各々の図 中の斜線範囲内は $273 \mathrm{~K}$ 以下の良好な CCTT を有する 肉盛溶接部を得ることのできる $\mathrm{Cr}$ 量及び適用溶込率に 対する適正 $\mathrm{Zr}$ 添加量の籁囲を示している。

下盛材として $\mathrm{Zr}$ 添加 $26 \mathrm{Cr}$-2 Mo 銅溶加棒を用いた 肉盛溶接部の曲げ姃性（Fig. 6 参照）は，溶込率の変動 及び $\mathrm{Zr}$ 添加量の変動により影響を受けやすい．特に， 溶込率 $15 \%$ の肉盛溶接部における啇正 $\mathrm{Zr}$ 添加量範囲は 非常に决く, 過剩の $\mathrm{Zr}$ 添加 (0.23\%以上) は後述する ごとく肉盛溶接部に凝固割れの発生をあたらす。このよ jに，26 Cr-2 Mo 系銅下盛容加棒において溶込率 $15 \%$ 〜35\%まで安定した良好な曲げ延性を確保できる最適 $\mathrm{Zr}$ 添加量は約 $0.2 \%$ であるが，その適正範囲は極的て
狭いてとがわかる.

下盛材として, $15 \mathrm{Cr}-2 \mathrm{Mo}$ 系鋼溶加棒使用時 (Fig. 8 参照）には，溶込率15\%及び25\%においては，比較的広 範な適正 $\mathrm{Zr}$ 添加量範因を有するものの, 溶込率 $35 \%$ で は下盛材に $\mathrm{Zr}$ 無添加加ら0.2\%程度までの $\mathrm{Zr}$ 添加溶加 棒を用いた場合，前述のごとく第一周目肉盛溶接部中に マルテンサイトが生成する。肉盛溶接部中にマルテンサ イトが生じた場合沈いいてす，PWHT の実施仙より肉 盛溶接部の曲げ延性の改善の可能なととが Fig. 8 から あわかる。しかしながら，実構造物に拈いては AW 状 態のままで使用される可能性むあるととを考虑した場 合, AW 材の CCTT は室温以上となり, AW 状態の曲 ヴ延性の著しい出化傾向が懸念される。

これに対し，19 Cr-2 Mo 系鋼溶加棒を用いた場合 (Fig. 7 参照)，溶込率15\%～35\%に招いて，安定して良 好な曲け姃性を有する広笧な適正 $\mathrm{Zr}$ 添加量範围が得ら れるのがわかる。すなわち，19 Cr-2 Mo 系鋼溶加棒に おいては, Zr 無添加 $19 \mathrm{Cr}-2 \mathrm{Mo}$ 鋼溶加棒を用い溶込率 $35 \%$ で作製した肉盛溶接部の曲げ延性を除き，約 $0.3 \%$ までの $\mathrm{Zr}$ 添加下盛溶加棒の採用に上り，溶込率15\% $35 \%$ の幅広い施工条件範田内で $273 \mathrm{~K}$ 以下の優れた CCTT を有する肉盛溶接部の確保加可能 となった。乙 の範畊の中で特に優れた曲げ延甠を得られるのは0.15〜 $0.25 \% \mathrm{Zr}$ の範囲であり, 試作した溶加棒では $19 \mathrm{Cr}-2$ Mo-0. $25 \mathrm{Zr}$ 鋼溶加棒を下盛材として用いた肉盛溶接部 は溶込率 15\% 35\% の䇛囲内において $263 \mathrm{~K}$ 以下の CCTT を有する最む良好な曲げ延性を確保できること が明らかとなった。

以上のように, 下盛材への $\mathrm{Zr}$ 添加低 $\mathrm{Cr}$ 系溶加棒の 使用により，低 $\mathrm{Cr}$ 系溶加棒屯しくは安定化元素添加溶 加棒使用のそれぞれ単独の対策では得ることのできな かったより優れた肉盛溶接部の曲げ延性改善が可能であ ることが明らかとなった。

しかしながら，今回の陚験に供したいずれの $\mathrm{Zr}$ 添加 低 $\mathrm{Cr}$ 系溶加棒を採用した場合においても，過度の溶加 棒中への $\mathrm{Zr}$ の添加（例えば, 溶込率25\%においては約 $0.3 \%$ 以上）は，Fig. 9 の $19 \mathrm{Cr}-2 \mathrm{Mo}-0.4 \mathrm{I} \mathrm{Zr}$ 鋼溶加 棒を用いた例のでとく肉盛溶接部中に凝固割れの発生す ることが認められた。したがって，凝固割れの発生と曲 げ延性改善效果の両者を勘案すると, $19 \mathrm{Cr}-2 \mathrm{Mo}$ 鎝の 場合, $\mathrm{Zr}$ 添加量は約 $0.25 \%$ とするのが妥当であるとい える。

\section{2 硬さ分布}

Fig. 10 K各種 $\mathrm{Zr}$ 添加低 $\mathrm{Cr}$ 系溶加棒の代表例とし て最も広範な曲げ延性改善領域を有するととが明らかと なった $\mathrm{Zr}$ 添加 $19 \mathrm{Cr}-2 \mathrm{M}$ 。 鋼溶加棒のうち，0.1\%及 び0. $25 \% \mathrm{Zr}$ を添加した溶加棒を用いて溶込率25\%で作 製された肉盛溶接部の AW 材及び PWHT 材に対する ビードに垂直な断面中の溶融境界線に対して直角方向の 硬さ分布を示す。なお，図中には此較材として $\mathrm{Zr}$ 無添 加の $19 \mathrm{Cr}-2 \mathrm{Mo}$ 鋼溶加棒を下盛材に用いた肉盛溶接部 AW 材及び PWHT 材の硬さ分布む併記している.

$\mathrm{AW}$ 材においては， $\mathrm{Zr}$ 添加量の差による硬さの相違 はほとんど羿められず，第一周目肉盛溶接部の硬さは約 Hv 210 であり，第二，三周目肉盛溶接部の硬さは約 Hv 230〜240であった.

一方, PWHT 材についても, $\mathrm{Zr}$ 添加量の差に上万硬 


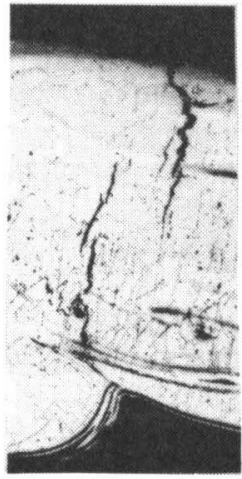

(a) bU0um

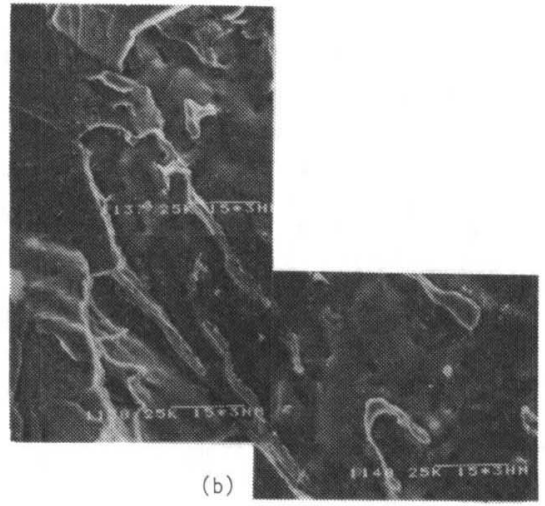

$15 \mu \mathrm{m}$

Fig. 9 Solidification cracking observed in the overlay weld metal using $19 \mathrm{Cr}-2 \mathrm{Mo}-0.41 \mathrm{Zr}$ steel as a filler metal for the first layer

(a) Optical microstructure (b) SEM microstructure

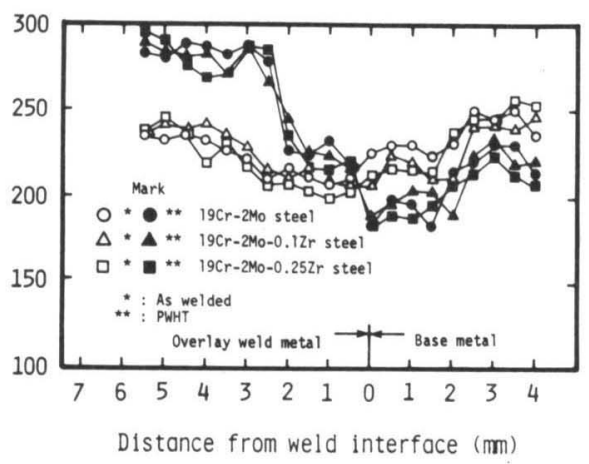

Fig. 10 Distribution of hardness in overlay welds

さの相違はほとんどなく，第一㬝目肉盛溶接部の硬さは 約 Hv 220, 第二, 第三層目肉盛溶接部のそれは約 $\mathrm{Hv}$ 280 と AW 材の同一位置に比へて Hv 50 程度硬化して いることがわかる。

\section{3 金属組織学的検討}

4. 3. 1 光学顕微鏡組織

Fig. 11 に Zr 添加量を0.10\%から0.25\%まで変化さ せた $19 \mathrm{Cr}-2 \mathrm{Mo}$ 鋼溶加棒を下盛材として用い, 溶込率 25\%の条件で溶接した代表的な肉盛溶接部 PWHT 材の 光学顕微鏡組織を示す.

肉盛溶接部中の結晶粒は溶融境界線から溶接金属中に 向かって成長しているのがみられる、第一首目肉盛溶接 部中の結晶粒径は, $\mathrm{Zr}$ 添加量が増加するにつれ, より 微細化する傾向が認められる。また, 第一層目肉盛溶接 部の結晶粒界は $\mathrm{Zr}$ 添加量の増加に伴い, よりジグザグ 状を呈するのがわかる. 第二層目より上層については, 溶加棒中の $\mathrm{Cr}$ 量及び $\mathrm{Zr}$ 添加量の変化に伴う結晶粒の 差異はほとんど梕められず，いずれの場合もその結晶粒 は粗大化傾向を示し, 結晶粒界の形状は直線状となる.

4.3.2 析出物の挙動

肉盛溶接部中に存在する析出物を調査するため, 肉盛 溶接部の曲げ延性改善に有効に作用する $19 \mathrm{Cr}-2 \mathrm{Mo}-$

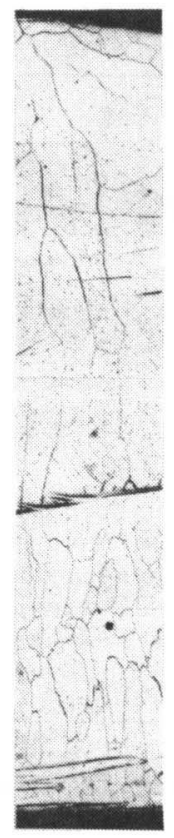

(a)

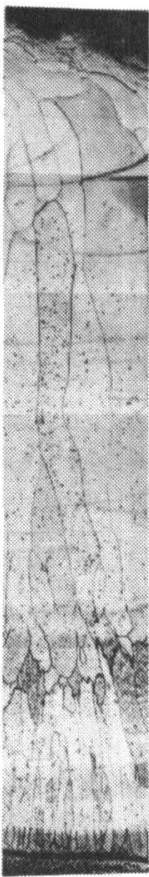

(b)

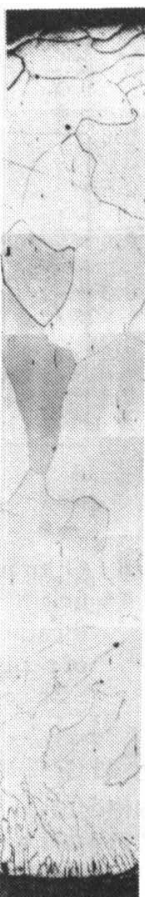

(c)

$0.5 \mathrm{~mm}$
Fig. 11 Microstructure of overlay weld metals post heat-treated

Filler metal (1st layer)

(a) $19 \mathrm{Cr}-2 \mathrm{Mo}-0.10 \mathrm{Zr}$ steel

(b) $19 \mathrm{Cr}-2 \mathrm{Mo}-0.16 \mathrm{Zr}$ steel

(c) $19 \mathrm{Cr}-2 \mathrm{Mo}-0.25 \mathrm{Zr}$ steel

Penetration ratio: $25 \%$

$0.25 \mathrm{Zr}$ 鋼下盛溶加棒を用いて溶込率 $25 \%$ で作製した肉 盛溶接部 PWHT の第一層目から抽出残渣を採取し, X 線回折による同定を行なった結果を Fig. 12 に示す。第 


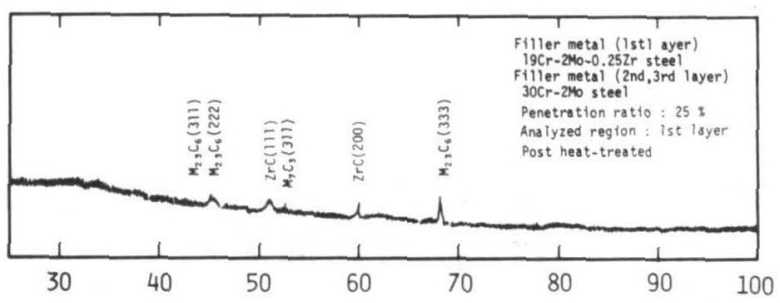

$2 \theta\left({ }^{\circ}\right)$

Fig. 12 X-ray diffraction pattern of residue extracted from the overlay weld metal post heat-treated Filler metal (1st layer)-: 19Cr-2Mo-0.25Zr steel Penetration ratio: $25 \%$ Analyzed region: 1st layer
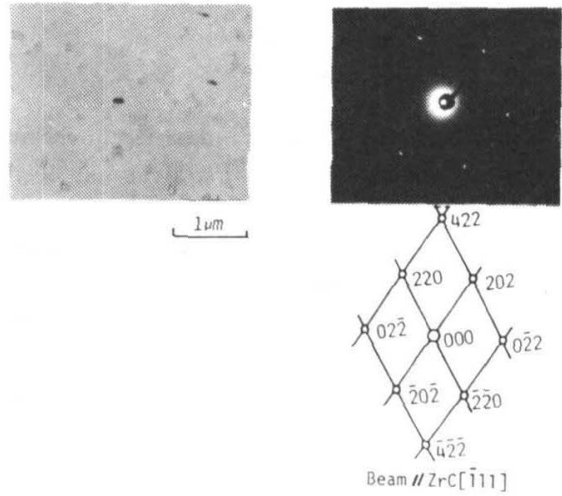

Fig. 13 TEM microstructure of precipitate in overlay weld metal post heat-treated and its diffraction pattern and key diagram

Filler metal (1st layer): $19 \mathrm{Cr}-2 \mathrm{Mo}-$ $0.25 \mathrm{Zr}$ steel

Penetration ratio: $25 \%$

Intragranular precipitate: $\mathrm{ZrC}$

一風目肉盛溶接部中には $\mathrm{M}_{23} \mathrm{C}_{6}, \mathrm{M}_{7} \mathrm{C}_{3}$ 及び $\mathrm{ZrC}$ の析 出が確認された。

$19 \mathrm{Cr}-2 \mathrm{Mo}-0.25 \mathrm{Zr}$ 鋼下盛溶加棒を用いて溶込率 $25 \%$ で作製された肉盛溶接部 PWHT 材の第一層目から 抽出レプリカを採取し, TEM による析出物の電子線回 折を行なった。 パターンの解析結果を Fig. 13 に示す. これより，第一層目肉盛溶接部の結晶粒内には $\mathrm{ZrC} の$ 存在が確慧された。

以上のような金属組織学的変化が $\mathrm{Zr}$ 添加低 $\mathrm{Cr}$ 系溶 加棒を下盛材に用いた場合の肉盛溶接部の曲げ延性改善 と密接な関連があると考えられるが，その改善機構に関 しては次報で考察を行なう。

\section{5. 結 論}

本報では, 第一㬝目肉盛溶接部に対して安定化元素添 加下盛溶加棒, 低 $\mathrm{Cr}$ 系下盛溶加棒及び安定化元素添加 ( $\mathrm{Zr}$ 添加) 低 $\mathrm{Cr}$ 系下盛溶加棒採用時の高純度フェライ ト系ステンレス鋼肉盛溶接部の曲げ延性についての検討 を通じて, 曲げ延性改善に最あ有効である下盛溶加棒の 最適組成の検討を行なった。
以下に，得られた結果を列記する。

(1) 安定化元素として $\mathrm{Nb}, \mathrm{Ti}$ むしくは $\mathrm{Zr}$ を取上 げ，これらを約 $0.1 \%$ 0.45\%の範囲内で添加した 30 Cr-2 Mo 鋼溶加棒を用いて作製した肉盛溶接部 PWHT 材に対する側曲げ試験の結果, 溶加棒への $\mathrm{Zr}$ 添加が曲 げ延性改善に最あ有効であるととが判明した。特に，30 $\mathrm{Cr}-2 \mathrm{Mo}-0.28 \mathrm{Zr}$ 鋼下盛溶加棒の採用により, $\mathrm{Zr}$ 無添 加の場合に比べて肉盛溶接部 PWHT 材の CCTTを $70 \mathrm{~K}$ 低下させることが可能となった。

(2) 下盛溶加棒中の $\mathrm{Cr}$ 量の低減により, 肉盛溶接部 PWHT 材の曲げ延性は向上する。しかしながら, Cr 量 の過度の低下は第一風目肉盛溶接部中に機械的特性に悪 影響を及ぽすマルテンサイトが生成するため, この相の 生成を抑制し, かつ, 良好な曲げ延性を確保するには 19 Cr-2 Mo 鋼下盛溶加棒の使用が最適であるととがわ かる. この際, 溶込率25\%の肉盛溶接部 PWHT 材にお いては $273 \mathrm{~K}$ の CCTT を得ることができる。

（3）下盛溶加棒の低 $\mathrm{Cr}$ 化を図り，同時に0.1 0.3\% の $\mathrm{Zr}$ を添加した場合, PWHT を施した肉盛溶接部の 曲げ延性を大幅に向上させることができる．その中であ $19 \mathrm{Cr}-2 \mathrm{Mo}-0.25 \mathrm{Zr}$ 鋼下盛溶加棒を用いた肉盛溶接部 PWHT 材は溶込率15\% 35\%までの溶接条件範囲内に おいて, $263 \mathrm{~K}$ 以下の CCTT を有する良好な曲げ延性 が得られることが明らかとなった。

(4) $\mathrm{Zr}$ 添加 $19 \mathrm{Cr}-2 \mathrm{Mo}$ 鋼下盛溶加棒を用いた第一 層目肉盛溶接部の結晶粒径は $\mathrm{Zr}$ 添加量の増加に伴い微 細化傾向を示すとともに, 結晶粒界はよりジグザグ状を 呈する.また, TEM 観察の結果, 結晶粒内には $\mathrm{Zr}$ の 析出が観察された.

\section{参考 文 献}

1) 中尾, 西本, 辰已, 野井, 塚原, 原, “肉盛溶接部の脆化現 象”, 溶接学会論文集, Vol.4(1986), No.3, p.527-533

2) 中尾, 西本, 山崎, 野井, 塚原, 原, “肉盛溶接部の脆化機 構”, 溶接学会論文集, Vol.5(1987), No.3, p.422-429

3）富士川, 須藤, 牧浦他, “含Z $\mathrm{r}$ フェライトステンレス鋼の成形性 及び溶接性”, 鉄と鋼,Vol.65(1979), No.7, p.1094-1103

4) Y. Nishio, T. Ohmae, Y. Yoshida and Y. Miura, "Weld cracking and mechanical properties of $17 \%$ chromium steel weldment", Welding Journal, 1971, p9s-19s

5) J. M. Sawhill, Jr and A. P. Bond, "Ductility and toughness of 
stainless steel welds", Welding Journal, 1976, p33s $\cdots 41$ s

6) 門, 山崎，山内，矢部，“ $18 \% \mathrm{Cr}$ 鋼の溶接部の鞠性におよほす合

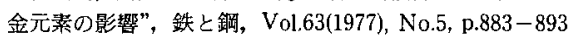

7) Anton L. Schaeffler, "Selection of austenitic electrodes for welding dissimilar metals", Welding Journal, 1974, Oct., $\mathrm{p} 601 \mathrm{~s}-620 \mathrm{~s}$

\section{$\mathrm{Zr}$ 添加低 $\mathrm{Cr}$ 系下盛溶加棒による肉盛溶接部の 曲げ延性改善機構*}

一高純度フェライト系ステンレスクラッド銓の溶接に關する研究（第 4 報）一 中尾嘉邦**，西本和俊**，山崎和信***野井伸悟****，塚原 宏*****，原 泰弘*****

Mechanism of Improvement of the Bend Ductility of the Overlay Weld prepared with Zirconium Containing Low Chromium type Steel Filler Metal*

-Study on Welding of the Low Interstitial Ferritic Stainless Clad Steel (Report 4)-

by Yoshikuni Nakao**, Kazutoshi Nishimoto**, Kazunobu Yamazaki***,

Shingo Noi****, Hiroshi Tsukahara***** and Yasuhiro Hara*****

The mechanism of improvement of the bend ductility of the low interstitial ferritic stainless steel overlay welds prepared with zirconium containing low chromium type steel filler metal for the first layer has been investigated.

In the previous report, it was indicated that the thickness of chromium carbide, $475^{\circ} \mathrm{C}$ embrittlement and grain coarsening were factors affecting embrittlement in the overlay welds.

Decreasing in chromium content in the first layer of the weld metal contributed to mitigation of $475^{\circ} \mathrm{C}$ embrittlement and decreasing of the thickness of chromium carbide on the grain boundary in the overlay weld metal. Addition of zirconium to the first layer of the ferritic stainless steel overlay welds made the thickness of chromium carbide decrease and also the grain size refine.

These resulted in an excellent weld ductility for the overlay welds.

Key Words: Low interstitial ferritic stainless steel, Overlay weld, Bend ductility, Improvement, Chromium carbide, grain size, $475^{\circ} \mathrm{C}$ embrittlement, Filler metal, Mechanism, Intergranular carbide thickness

\section{1. 緒}

需

前報1-3)までにおいて,肉盛溶接部の曲げ延性は，下盛 材への $\mathrm{Zr}$ 添加低 $\mathrm{Cr}$ 系溶加棒の採用により大幅佂改善 されることが明らかとなった，特に，下盛材として 19 Cr-2 Mo-0. $25 \mathrm{Zr}$ 鋼溶加棒を用いた場合には，溶込渂 15 \%〜35\%までの幅広い溶接条件範囲において, 安定して 良好な曲げ延坐を有する肉盛溶接部を得るととが可能と なった。

しかしながら， $\mathrm{Zr}$ 添加低 $\mathrm{Cr}$ 系下盛溶加棒の使用に上 る肉盛溶接部の曲げ延性改善に対して，粒界の $\mathrm{Cr}$ 岸化 物幅, $475^{\circ} \mathrm{C}$ 脆化及び結晶粒径が影響を及ぼしているも のと推察されているすのの，その詳細についてはいまだ 不明である。

本報においては，下盛材への $\mathrm{Zr}$ 添加低 $\mathrm{Cr}$ 系溶加棒

"原稿㥅付 昭和62年11月11日 昭和61年度春季全国大会で発表

**正 員 大阪大学工学部 Member, Faculty of Engineering Osaka University

**正員. 大阪大学大学院 (現在：日新製鋼（株)） Member, Graduate school,Osaka University(Present address:Nisshin Steel Co, Ltd.

****正員 (株)新潟鉄工所 Member, Niigata Engineering Co.,Ltd.

(株) 新潟鉄工所 Niigata Engineering Co.,Ltd.
使用時の肉盛溶接部の曲げ延性改善機構の解明を目的亡 して，前報までに明らかにした肉盛溶接部の脆化要因 (粒界の $\mathrm{Cr}$ 炭化物楅, $475^{\circ} \mathrm{C}$ 脆化及び結晶粒徍) の変 化に着目して検討を行なった。

\section{2. 供試材料ならびに実験方法}

本試験に供した肉盛溶接部は，Table 1 中の溶加棒を 用いて，板厚 $38 \mathrm{~mm}$ の炭素銓板上にティグ法により， 溶込率15\% 35\%の範囲で下盛溶接を行なった後，その 上周には市販の高純度 $30 \mathrm{Cr}-2 \mathrm{Mo}$ 鋼溶加棒 (Table 1 中のHM）を用い，溶込率25\%で肉盛溶接を行なうこと により作製した。

肉盛溶接部の組織観察は，光学顕微鏡及び走查型電子 湿微鏡（以後 SEM と呼ぶ）を用いて行なった。乙れら

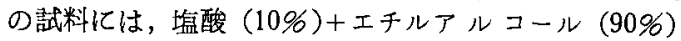
溶液中で電圧 $35 \mathrm{~V}$ で $20 \mathrm{~s}$ 間の電解研磨の後, 電圧 $3 \mathrm{~V}$ で $10 \mathrm{~s}$ 間の電解腐食を行なった。肉盛溶接部の破面観 祭には SEM を用い，その試料涪部破面上の析出物

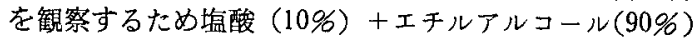
溶液を用い，電圧 3 Vで $20 \mathrm{~s}$ の電解廊食を行ない，粒界 を現出させ観察に供した。 Table 2 に第 2 報2)で用いた 高純度 $30 \mathrm{Cr}-2 \mathrm{Mo}$ 鋼を炭素鋼上に肉盛溶接した場合の 第一周目肉盛溶接部をシミュレートするため, $\mathrm{Cr}$ 量を 26\%に低下させ，C 舅を0.002 0.049\%の範围で 5 段階 に変化させた引張試験材の化学組成を示す。これらの釦 